УДК 636.32/.38:619:616.99:631.11(477.64)

(C) 2016

Свстаф'єва В. О., доктор ветеринарних наук,

Мельничук В. В., асистент,

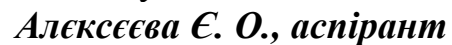

(науковий керівник - доктор ветеринарних наук В. О. Свстаф'єва)

Полтавська державна аграрна академія

\title{
ПОШИРЕННЯ МЕЛОФАГОЗУ ОВЕЦЬ У ГОСПОДАРСТВАХ ЗАПОРІЗЬКОӤ ОБЛАСТІ
}

\section{Рецензент - доктор ветеринарних наук А. А. Замазій}

\begin{abstract}
Наведені результати клінічних та паразитологічних досліджень щзодо вивчення ступеня інвазованості овець Melophagus ovinus в умовах господарств з різними формами власності (сільськогосподарські підприємства, фермерські та особисті селянські господарства) на території Запорізької області. Встановлено, шуо середня екстенсивність мелофагозної інвазії вівиепоголів'я становила 29,51\% за інтенсивності

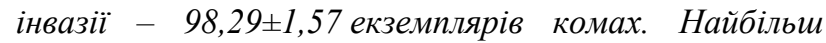
ураженими збудником мелофагозу виявилися вівиі, які утримувалися в особистих селянських та фермерських господарствах, ніж тварини, щзо належали сільськогосподарським підприємствам.
\end{abstract}

Ключові слова: вівиі, мелофагоз, поширення, екстенсивність, інтенсивність інвазї.

Постановка проблеми. Сьогодні вівчарство, як і тваринництво взагалі, набуває вагомого соціально-політичного значення. В умовах українського ринку галузь продовжує існувати тому, що крім продуктів харчування, сировини для медичної і фармакологічної промисловості, вівці продукують вовну, альтернативну синтетичним волокнам природну сировину, яка в епоху наростання енергетичної кризи згодом може посісти провідне місце в задоволенні потреб людства [2, 4].

Запорукою успішного розвитку вівчарства $\epsilon$ ветеринарне благополуччя поголів'я. Серед захворювань овець заразної етіології значне місце посідають ектопаразитарні хвороби, зокрема мелофагоз, який завдає галузі значних збитків через втрату м'ясної та вовнової продуктивності, загибелі молодняку $[1,6,7]$.

Аналіз останніх досліджень і публікацій, у яких започатковано розв'язання проблеми. Про значне поширення мелофагозу овець у господарствах різної форми власності свідчать роботи науковців США [13], Канади [12], Австралії [11], Франції [9], Англії [10] та інших країн світу.

Дослідники повідомляють про значне розповсюдження мелофагозної інвазії на території вів- цегосподарств Російської Федерації. Так, середня інвазованість овець мелофагами у Гірському Алтаї становила 38,9 \% та 186,6 екземплярів комах [6]. У господарствах Тюменської області кількість мелофаг на вівцях різних вікових груп коливалася в межах від 13 до 3700 екземплярів [5]. На території Республіки Башкортостан мелофагоз овець зареєстрований у господарствах 10 регіонів, де екстенсивність інвазії могла сягати $100 \%$ [1].

На території господарств України мелофагоз овець - хвороба, якій приділялося науковцями недостатньо уваги. $€$ окремі повідомлення, які свідчать про спалах мелофагозу на фермі Харківської області у випадку спільного утримання кіз і овець. Екстенсивність мелофагозної інвазії у досліджених овець становила $65,4 \%$ за інтенсивності інвазії - 118,4 $\pm 12,7$ екз. на тварину [3].

Мета досліджень - вивчити поширення мелофагозу овець на території господарств Запорізької області.

Завданнями досліджень було визначити показники екстенсивності та інтенсивності мелофагозної інвазії у овець в господарствах різних форм власності.

Матеріали і методи досліджень. Дослідження проводилися упродовж 2015-2016 рр. на базі наукової лабораторії кафедри паразитології та ветеринарно-санітарної експертизи Полтавської державної аграрної академії. Клінічні обстеження овець проводили в умовах вівцегосподарств 3 різною формою власності (сільськогосподарські підприємства 3 потужністю утримання від 312 до 984 голів і одноосібні та фермерські господарства 3 потужністю від 4 до 35 голів) на території Запорізької області (Новомиколаївського, Веселівського, Мелітопольського, Оріхівського, Токмацького, Запорізького і Бердянського районів). Досліджували овець порід романовська, асканійська тонкорунна та курдючна віком від 4 місяців до 5 років.

Інвазованість овець збудником мелофагозу 


\section{ВЕТЕРИНАРНА МЕДИЦИНА}

вивчали шляхом повного обстеження волосяного покриву тварин. Відловлювали комах за допомогою пальців і анатомічного пінцета $[6,8]$. Від кожної тварини членистоногих збирали в окрему склянку, фіксували спиртом та етикетували. Основними показниками інвазованості овець були екстенсивність та інтенсивність інвазії (ЕI, II).

Результати досліджень. За результатами проведених паразитологічних досліджень овець мелофагоз виявився поширеною інвазією в умовах господарств Запорізької області. Середня екстенсивність мелофагозної інвазії становила 29,51\%, за інтенсивності інвазії 98,29 $\pm 1,57$ екз. комах. Причому показник II коливався в межах від 9 до 301 комах на тварині (табл. 1).

Згідно 3 даними таблиці 1, екстенсивність мелофагозної інвазії в різних районах Запорізької області знаходилася в межах 16,67-61,63\%. Так, найвищу інвазованість овець мелофагами реєстрували у господарствах Бердянського (61,63\%), Токмацького (51,07 \%), Оріхівського (46,83\%) та Запорізького (30,58 \%) районів. Менш ураженим виявилося вівцепоголів'я Веселівського (16,67\%), Мелітопольського (115,93 $\pm 3,18$ екз.), Новомиколаївського (19,95\%) районів. Показники інтенсивності мелофагозної інвазії овець у різних районах коливалися в межах від $48,94 \pm 1,65$ до $115,93 \pm 3,18$ екз. комах на тварині.
Максимальну кількість комах виявляли на тваринах в господарствах Мелітопольського (18,64 \%), Запорізького $(105,66 \pm 6,05$ екз.), Оріхівського (110,05 $\pm 3,41$ екз.) районів. У вівцегосподарствах Веселівського, Бердянського, Новомиколаївського, Токмацького районів кількість виявлених

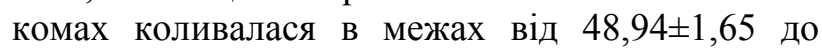
97,95 $\pm 2,97$ екземплярів.

Установлено, що ступінь ураження овець мелофагами був вищим у особистих селянських та фермерських господарствах, в яких утримується невелика кількість овець (від 4 до 35 голів), ніж у сільськогосподарських підприємствах (табл. 2).

Так, показники екстенсивності та інтенсивності мелофагозної інвазії овець у сільськогосподарських підприємствах дорівнювала відповідно

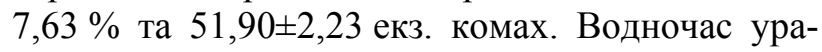
женість тварин в особистих та фермерських господарствах була значно вищою i становила $51,69 \%$ та $105,05 \pm 1,65$ екз. комах. На нашу думку, така різниця у показниках інвазованості овець пов'язана 3 тим, що у господарствах 3 невеликою кількістю тварин їх ветеринарносанітарний стан знаходиться на низькому рівні, а також не завжди вчасно проводиться стрижка овець, що призводить до сприятливих умов розвитку мелофаг та розповсюдження ентомозу.

\section{1. Поширення мелофагозу овець у господарствах Запорізької області}

\begin{tabular}{|c|c|c|c|c|}
\hline Район & $\begin{array}{c}\text { Досліджено } \\
\text { (гол.) }\end{array}$ & $\begin{array}{c}\text { Інвазовано } \\
\text { (гол.) }\end{array}$ & $\begin{array}{c}\text { EI, } \\
\%\end{array}$ & $\begin{array}{c}\text { II, екз. комах на тварину, } \\
\text { M } \pm \mathrm{m}(\min -\text { max })\end{array}$ \\
\hline Веселівський & 312 & 52 & 16,67 & $51,90 \pm 2,23(9-88)$ \\
\hline Бердянський & 258 & 159 & 61,63 & $86,45 \pm 3,47(12-227)$ \\
\hline Запорізький & 206 & 63 & 30,58 & $105,66 \pm 6,05(27-221)$ \\
\hline Мелітопольський & 1422 & 265 & 18,64 & $115,93 \pm 3,18(11-301)$ \\
\hline Новомиколаївський & 381 & 76 & 19,95 & $48,94 \pm 1,65(13-92)$ \\
\hline Оріхівський & 378 & 177 & 46,83 & $110,05 \pm 3,41(20-267)$ \\
\hline Токмацький & 374 & 191 & 51,07 & $97,95 \pm 2,97(24-233)$ \\
\hline Всього & 3331 & 983 & 29,51 & $98,29 \pm 1,57(9-301)$ \\
\hline
\end{tabular}

\section{2. Показники екстенсивності та інтенсивності мелофагозної інвазиї овець у господарствах залежсн від форми власності та потужності}

\begin{tabular}{|c|c|c|c|c|c|}
\hline $\begin{array}{c}\text { Форма власності } \\
\text { господарства }\end{array}$ & $\begin{array}{c}\text { Потужність } \\
\text { господарства } \\
\text { (гол.) }\end{array}$ & $\begin{array}{l}\text { Досліджено, } \\
\text { (гол.) }\end{array}$ & $\begin{array}{l}\text { Інвазовано, } \\
\text { (гол.) }\end{array}$ & $\begin{array}{l}\mathrm{EI}, \\
\%\end{array}$ & $\begin{array}{c}\text { II, екз. комах } \\
\text { на тварину, } \\
\text { M } \pm \mathrm{m}\end{array}$ \\
\hline $\begin{array}{c}\text { Сільськогосподарські } \\
\text { підприємства }\end{array}$ & $312-984$ & 1677 & 128 & 7,63 & $51,90 \pm 2,23$ \\
\hline $\begin{array}{c}\text { Особисті селянські та } \\
\text { фермерські }\end{array}$ & $4-35$ & 1654 & 855 & 51,69 & $105,05 \pm 1,65$ \\
\hline
\end{tabular}




\section{ВЕТЕРИНАРНА МЕДИЦИНА}

\section{Висновки:}

1. Мелофагоз овець $є$ поширеною інвазією на території Запорізької області, середня екстенсивність інвазії становить 29,51\%, інтенсивність -

\section{БІБЛІОГРАФІЯ}

1. Абдуллин Ш. М. Мелофагоз овец и разработка мер борьбы с ним в Республике Башкортостан : дисс. ... к.вет.н. : 03.00.19 / Ш. М. Абдуллин. Уфа, 1999. - 158 с.

2. Аграрний сектор економіки України (стан i перспективи) / [Присяжнюк М. В., Зубець М. В., Саблук П. Т. та ін.]. - К., 2011. - 1008 с.

3. Бырка В.И. Распространение Melophagus ovinus (Diptera: Hippoboscidae) и борьба с ней в неблагополучном хозяйстве / В.И. Бырка, А. В. Мазанный // Ученые записки УО «ВО «Знак Почета» государственная академия ветеринарной медицины». - Витебск, 2015. - Т. 51, Вып. 1, Ч. 1. - С. 174-178.

4. Вдовиченко Ю. В. Стан та перспективи розвитку галузі вівчарства України / Ю. В. Вдовиченко, П. Г. Жарук // Вісник Дніпропетровського державного аграрного університету. - 2013. - №1. - С. 136-138.

5. Домацккая М. Д. Экстенсивность и интенсивность поражения овец кровососками в Тюменской области : сб. науч. тр. «Вопросы ветеринарной арахно-энтомологии». - Тюмень, 1974. Вып. 5. - С. 25-29.

6. Земиров Ю. С. Энтомозы овец горного Алтая : дисс. ... к.вет.н. : 03.00.19 / Ю. С. Земиров. Горно-Алтайск, 2005. - 180 с.

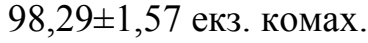

2. Найвищу інвазованість овець встановлено в особистих i фермерських господарствах (EI $51,69 \%$, II - 105,05 $\pm 1,65$ екз. комах).

7. Курхули Н. Р. Патогенез мелофагоза овец и меры борьбы с ним в условиях Нечерноземной зоны РСФСР : дисс. ... к.вет.н. : 03.00.19 / Н. Р. Курхули. - М., 1984. - 132 с.

8. Третьяков A. М. Лабораторная диагностика паразитарных заболеваний животных / А. М. Третьяков, П. И. Евдокимов, В. А. Шабаев. Улан-Удэ, 2006. - 40 с.

9. Dufour L. Studes auatawiques et physiologiques sur le inseets de la fanille de Pupipares / L. Dufour // Ann. el. sc. Nature. - 1843. - Vol. 3, VIII. - P. 46-96.

10. Evans G. O. A method for observing the life cycle of Melophagus ovinus / G. O. Evans // Nature. 1946. - Vol. 157, №3997. - P. 773.

11. Heath A. C. G. Recent insecticides: their efficacy as plunge dips against the bitting louse, Damalinia ovis and the ked, Melophagus ovinus, on sheep / A. C. G. Heath, E. S. Millar // Veter. J. - 1970. Vol. 18 (10). - P. 211-213.

12. Nelson $W . A$. Weight gain Woel growth in sheep infected with the sheep ked: Melophagus ovinus / W. A. Nelson, S. B. Slen // Exp. Parasitol. 1968. - Vol. 22, №2. - P. 223-226.

13. Pfadt R. E. Further tests with power dusting to control the sheep ked / R. E. Pfadt, R. J. Lavigne // J. Econ. Entomol. - 1965. - Vol. 58, №1. - P. 37-38. 